\title{
Beyond the Screen: Uneven Geographies, Digital Labour, and the City of Cognitive-Cultural Capitalism
}

\author{
Dillon Mahmoudi ${ }^{*}$, Anthony Levenda ${ }^{\dagger}$ \\ Portland State University, Portland, Oregon, USA, ${ }^{*}$ dillonm@pdx.edu, \\ †anthonylevenda@pdx.edu
}

\begin{abstract}
In this paper, we demonstrate that an examination of the socio-environmental impacts of digital Information and Communication Technologies (ICTs) remains a fruitless enterprise without "materializing" digital labour. We suggest a two-part approach to materializing digital labour: first, connecting political economic analyses of digital ICTs to the co-evolution and geography of planetary urbanization and technological change, and second, examining the relationships between immaterial, digital labour and the material industrial production system. In the context of broad changes in technology, social life, and urbanization, many scholars have theorized a shift towards a third phase of capitalism, beyond mercantilism and industrialism, based in immaterial, digital, and cognitive labour. We introduce the literature on cognitive-cultural capitalism and third-wave urbanization as markers of contemporary capitalism, producing uneven socio-spatial arrangements across the global-urban system. Synthesis of media and communication studies and political economies of urbanization suggests that both capital accumulation and the social lives of (planetary) urban residents are increasingly mediated and structured by online, digital ICT platforms. We show that digital ICTs are sophisticated manipulations of nature that require and illuminate new ways of thinking about digital labour, and more broadly, of immaterial labour. We suggest that the immaterial labour associated with digital ICTs is actually material labour responsible for increasing the velocity of capital circulation, as a moment of production and an appendage of the growing complexity of third-phase capitalist industry and urbanization. The materiality of cognitive, cultural, and symbolic labour reaches beyond the city, invades the lifeworlds of a planet of urban residents, and excretes concrete, silicon, bits, servers, and energy waste producing an urban landscape beyond the city. Through an examination of data centres, we show the necessary relationship between the third-wave urbanization and its planetary reach into rural, pristine Oregon. Data centres in Oregon and the broader Pacific Northwest highlight the uneven geography of "clean" digital labour focused in large urban technopoles; the potentially harmful, material, and socioenvironmental impacts of data centres in rural areas; and the necessary and dialectic relationship between the two for cognitive-cultural capitalism. We argue that third-wave urbanization, and the concurrent and co-produced technological advancement in digital ICTs and digital ICT infrastructure, creates the conditions for capital's subsumption of cognitive and cultural labour.
\end{abstract}

Keywords: digital labour, cognitive-cultural capitalism, circulation, third-wave urbanization, urban political ecology, digital ICT infrastructure, data centres

Acknowledgement: The authors would like to thank the tripleC editors, two anonymous reviewers, and Sy Adler for insightful comments on an earlier version of this paper. The authors would also like to thank attendees at the "Code/Nature and the Political Ecologies of Technology" panel session at the 2015 Dimensions of Political Ecology conference in Lexington, Kentucky for initial direction on this paper.

\section{Introduction: Social, Economic, and Technological Transformations}

All that is solid melts into tweets (Wyly 2013, 391).

Society has completely urbanized (Lefebvre 1992, 1 [1970]).

In the "phantasmagorical" contemporary networked city, technological networks are interlinked in an integrated "machinic complex" of speed, light, and power (Amin and Thrift 2002). Information and communication technologies (ICTs) have co-evolved with cities, enabling ever more seamless integration and ubiquity in the urban fabric (Graham and Marvin 2001; 
Sussman 1999). Undergirding and co-shaping spatial, social, and political-economic transformations have been the development of digital ICTs, the internet, and webbased platforms for social media. The social lives of urban residents have increasingly taken place on social media sites, structured by capitalist business platforms such as Facebook (Zip, Parker, and Wyly 2013). Castell's (1996) space of flows and space of places are in a dialectical tension, caught up in the mix of twinned processes of technological change and urbanization as both urbanism and Facebook become a way of life. ${ }^{1}$

The broad changes in technology, social life, and urbanization have led many scholars to theorize a shift towards a third phase of capitalism, beyond mercantilism and industrialism, based in immaterial, digital, and cognitive labour. Cognitive capitalism, as Autonomist Marxists and others call it (cf Peters and Bulut 2011), is marked by an accumulation process centred on immaterial inputs, immaterial and digital labour processes, and production of immaterial goods such as services, cultural products, knowledge or communication (Peters and Bulut 2011; Hardt and Negri 2004). Scholarship both within urban and economic geography and media and communication studies have questioned the implications of this third phase of capitalism, or "cognitive cultural capitalism" (Scott 2009; Scott 2014), particularly in relationship to questions of space, place, time, and the division of labour. The overwhelming focus on the immaterial aspects of cognitive-cultural capitalism, however, obfuscates the materiality and socio-environmental foundations of capital accumulation and circulation. Today's technological circumstances further complicate analysis on capital, labour, production, and circulation because of the continued changing nature of goods:

\begin{abstract}
A good deal of confusion has arisen over the changing physical nature of goods... This derives in part from increasingly sophisticated manipulations of nature involved in modern production, particularly via electronics. Many people have antiquated notions of goods derived from the mechanical age. They fail to see that a computer program, which takes the form of electrons on a tape or disk, is every bit as much material good as a chair. It was produced by labor, it has continuing existence, and it performs a useful function. It has a discrete and tangible form, unlike a true labor-service. The real distinction here is between tactile and non-tactile goods, or things that are easily seen and grasped and those that are not (Walker 1985, 50-51, emphasis added).
\end{abstract}

One of our main contentions is that digital ICTs are "sophisticated manipulations of nature", bringing new light to notions of digital and immaterial labour. We suggest that the immaterial labour associated with digital ICTs is actually material labour involved in increasing the circulation velocity (or rate) of capital. That is, digital labour uses digital ICTs and builds on existing material infrastructures to increase the speed that capitalists realize profit. Cognitive labour and the immense network of fixed capital infrastructures that support it are an appendage of the growing networks of third-phase capitalist industry and urbanization. Digital ICTs and digital infrastructures, as Walker suggests, are "the things that are not easily seen and grasped." Therefore, an unearthing of infrastructures of digital ICTs, especially those beyond the screen, is an essential task for understanding the socio-environmental impacts of digital ICTs.

In this article, we highlight how socio-material processes and circulations of capital produce uneven geographies. We utilize the framework of urban political ecology (UPE) to trace how planetary urbanization under cognitive-cultural capitalism (CCC), or "third-wave urbanization" (Scott 2009; Scott 2014), mandates new forms and physical expressions of the circulation of capital. Landmark work in UPE has focused primarily on water infrastructure (cf Swyngedouw, Kaika, and Castro 2002; Swyngedouw 2009; Loftus 2012) or urban trees (Heynen, Perkins, and Roy 2006), but the technological realms of energy, communication, and information infrastructure are largely unaddressed. Existing studies have focused on political ecologies within the city and less so on the socio-ecological processes which pro-

\footnotetext{
${ }^{1}$ This refers to Louis Wirth's (1938) seminal paper, "Urbanism as a way of life", originally published in The American Journal of Sociology. His contribution was extended by Zip et al (2013) in their formulation as "Facebook as a way of life" describing the contemporary networked relations of an increasingly urban world.
} 
duce the city and the configurations of city networks that are both manifestations of capital circulation and means for further capital accumulation. As Angelo \& Waschmuth argue, "urban political ecology (UPE) has done an exemplary job of investigating environmental questions in cities, [but] it has been curiously quiet on the very feature of the contemporary urban world that should make it so relevant: the dimensions of urbanization processes that exceed the confines of the traditional city" $(2014,2)$. Our study responds to Angelo \& Waschmuth's critique through examination of data centres in rural Oregon, a critical infrastructure of thirdwave urbanization and digital labour. Cities of cognitive-cultural capitalism are reliant on these energy-intensive data infrastructures to facilitate digitally-enabled cognitive and cultural industries, creating and reproducing a new division of labour that (re)inscribes social disparities in the uneven geographies of the city and landscapes beyond.

\section{Third-Wave Urbanization}

To examine the socio-environmental impacts of digital labour requires an interrogation of how digital labour is distributed and divided in space. We add a geographical dimension to the political economy of digital labour by connected digital labour to the social, technical and capitalist process of urbanization. The study of urbanization, as a process, mandates a focus on the networked, spatialized and digital aspects of capitalism's contemporary phase, cognitive-cultural capitalism. Following urban geographer and political-economist Allen J. Scott, we use the notion of CCC to synthesize the heterodox evolution of two strains of thought. Firstly, we take concepts like post-Fordism, flexible accumulation, and flexible specialization from the studies on labour and industry to analyse the capitalist changes in industrial organization since the 1970s (Bluestone and Harrison 1982; Harrison and Bluestone 1985; Scott 1986; Piore and Sabel 1986; Storper and Walker 1989; Amin 1994; Massey 1995; Markusen and Schrock 2006). Secondly, we take concepts of cognitive-capitalism (sans cultural) which stress the dialectic relationship in the production processes between capital and labour amidst structural changes to suggest a new form of subsumption (of social reproduction, culture, knowledge) (Vercellone 2007; Terranova 2000; Scholz 2012; MoulierBoutang 2012). Each attempts to describe a different facet of the uneven and broad changes associated with the intensification of production and the fungibility of both capital and labour made possible by technological advancement, spatial reorganization and new forms of cognitive labour. As a historical moment of capitalism, we can integrate these two literatures and characterize CCC with three central markers:

(1) the new forces of production that reside in digital technologies of computing and communication; (2) the new divisions of labour that are appearing in the detailed organization of production and in related processes of social re-stratification, and (3) the intensifying role of mental and affective human assets (alternatively, cognition and culture) in the commodity production system at large (Scott 2011b, 846).

Scott's empirical observations and theorizations support the notion that the cognitivecultural system of production is transforming the economic foundations of urban regions worldwide. More specifically, these inter-related markers taken from Scott's work describe the crucial components of CCC that relate specifically to digital labour.

First, calculation, communication and information storage are performed using digital methods. Digital methods reduce the costs of transportation and storage while also reducing the time necessary for communication. For the capitalist, this has significant impacts for command and control operations, changing the nature of production and organization. Second, urbanization processes include new divisions of labour with implications for the restratification of urban labour and social life. Scott defines this division between two distinct classes: highly qualified symbolic analysts, and a low-wage service underclass or a new servile class (2011). The former perform functions using knowledge, cognition and symbols (cognitive-cultural workers) while the latter perform service functions as either manual labour or menial service labour. Lastly, these productive changes are also reflected in consumption. Consumers spend larger shares of their income on large and varying palette of 
goods and services that have potent experiential significance. Furthermore, the social, economic, and technological changes characteristic of cognitivecultural capitalism shape, and are shaped, by the built environment of the city. These changes are characterized by new and altered land uses and an "aestheticized land-use intensification." The result is the production of spectacular architectural gestures that "world" cities and serve largely as monuments to transnational corporate power (Scott 2011b).

A basic understanding underlies this point: capitalist urbanization is a socio-spatial process resulting in spaces of intensified economic activity, and as such, is represented by agglomerations of capital and labour. Cities are densities of production and social reproduction necessary for capitalism's own reproduction. Contemporary cities of CCC can be recognized by their predominance in the digital, cultural, or informational economy, or as Scott calls them, "cynosures of the so-called 'new' economy" (2011a, 290), and furthermore, by their functional character as key nodes in global relationships of the networked urban society.

In other words, cities are socio-material spaces that are shaped and reshaped for capital accumulation. Of course, this is not to diminish other powerful forces that shape cities and their growth or decline, but instead, to show that CCC has developed, and is developing, alongside technological advancement, market extension and globalization (Scott 2011a). Here, again, the role of digital ICTs are important. For example, Zip, Parker and Wyly note that national rates of urbanization are correlated with national rates of market penetration for Facebook (2013).

[The] occurrence of two historically unprecedented phenomena: a majority-urban world, and a world where billions of people can and do regularly engage in social relations through dynamic networks transcending geographical proximity. As the world has become 'urban,' social media has transformed key facets of urban social relations while also diffusing them across suburban and rural areas (Zip, Parker, and Wyly 2013, 84).

This should be no surprise. Technology is co-evolving with planetary urbanization (Wyly 2013). Dialectically related to the historical development of capitalism, cities are outcomes of larger urbanization processes that reflect the dominant mode of production and system of socio-metabolic organization, or capitalism.

\subsection{Planetary Urbanization, Circuits, and the Circulation of Capital}

Scott's notion of the third-phase of capitalism can be counterpoised against the work of marxian social theorist Henri Lefebvre. Lefebvre posited that urbanization is the dominant form of capital accumulation, supplanting industrialization as the motor of capital accumulation (2003 [1970]). David Harvey argued, conversely, that the city was shaped by industrial capitalism, i.e. industry created the conditions for urbanization, and this was especially apparent in the circulation of surplus value produced by capital accumulation. We see both of these processes concurrently. The spatial organization of capitalist urbanization is marked by unevenness, with booming edges marked by suburban development, industry, and slums and favelas while the urban centres are simultaneously undergoing rapid gentrification. Industrial expansion tends to lead to a regional convergence in capital legibility, increased capital mobility and spatial differentiation foster continued unevenness (Walker 1978). Highly mobile global capital descends on urban centres, inscribing and re-inscribing the logics of capital accumulation in the urban landscape (Smith 2005). Urbanization may not be the dominant regime of capital accumulation, but it is certainly planetary in both scale and reach.

The recent explosion of research into planetary urbanization supports and expands Lefebvre's argument (Brenner and Schmid 2014; Brenner and Schmid 2015; Brenner 2013; Merrifield 2012; Merrifield 2013a; Merrifield 2013b). Lefebvre was concerned with the "complete urbanization of society", and not "urban society", because he wanted to transgress the infatuation of studies on the object of the city. In The Urban Revolution, Lefebvre sought to study the urban fabric-a virtual and theoretical object that embodies the notion that city 
has dominated the countryside (and everything else) in social, mental, and physical space which mandated the study of the urban, not the city. Lefebvre's thesis necessitated a conceptualization of how capital shapes not only the urban landscape, but also the concepts and categories of space and time. As Andy Merrifield (2013b, 913) argues, Lefebvre did this to show how the urban is a concrete abstraction - an actual reality and a concept of reality. We argue for a connection between Lefebvre's theory and David Harvey's work on 'the urbanization of capital' (Harvey 1981; Harvey 1989), which shows how capital flows through at least three circuits: primary, secondary and tertiary. The primary circuit relates to investment in commodity production, but often confronts the crisis of overaccumulation necessitating a "capital switch" to the secondary circuit (Christophers 2011). The secondary circuit relates to investment in fixed capital (factories, machinery, technologies, and the built environment for production, e.g. roads, rail, infrastructures) or a consumption fund (commodities that aid in consumption or the built environment for consumption). The tertiary circuit is an overflow container for overaccumulation in the secondary circuit. It includes investments in science and technology, and social expenditures that enhance labour's productivity or reduces social anguish and strife to secure consensus with labour.

Building on Merrifield's interpretations, we can explain Lefebvre's thesis in relation to the secondary circuit of capital. As Merrifield notes:

Flows of investment that produce space, that seemingly have the same vital, spontaneous energy of a Pollock loop, power the 'secondary circuit' of capital into real estate, a circuit of investment that formerly ran parallel to the 'primary circuit' of capital, to industrial production, but which now, Lefebvre says, has grown to be relatively more important in the overall global economy (2013b, 914-915).

Engaging with the Lefebvrian notion of planetary urbanization, Harvey (2014) more recently has suggested that capital cannot exist without the processes of urbanization. He, as in earlier work, claims urbanization is absolutely "vital to the reproduction of capital accumulation and the reproduction of the power of the capitalist class" (2014). The boom in urbanization is entirely about "absorbing surplus capital, sustaining profit levels, and maximizing the return on exchange values no matter what the use value demands might be," creating the conditions for the crisis of planetary urbanization.

In Lefebvre's thesis of planetary urbanization, the secondary circuit predominates while the primary circuit dwindles away, impacting labour, as a condition of post-employment emerges. Lefebvre, explained that on the one hand, information technology and automation facilitate, mature, and expand the urban toward planetary dominance. On the other hand, information technology and automation mean that "post-employment ensues, coupled with more planetary urbanization, and more industrial contradictions that now somehow manifest themselves as global-urban contradictions" (Merrifield 2013a, 21). Unemployment, or at least unsalaried/waged work, is "structurally inseparable" (2013a, 21) from the dynamic of accumulation and expansion-urbanization on a planetary scale for Lefebvre - which constitutes the very nature of capitalism as such (Merrifield 2013a; Merrifield 2012).

In conjunction with what Merrifield calls the urbanization of the general intellect, we take this point to clarify the relationship of urbanization with immaterial and digital labour, but we problematize the claim that immaterial labour will be the demise of capitalism in the long run. Instead, we see immaterial labour as dialectically related to material labour. We discuss this further in the next section, referencing Fuchs (2014) work on the international divisions of digital labour, but want to highlight here that as immaterial labour grows, replaces and distances or peripheralizes material labour, the secondary circuit of capital takes on a greater role. Fixed capital, or dead labour, replaces living labour:

When the world of work is dominated by machines, when we become appendages to machines, to new technology, to informational digitized technology, when technology "suspends" human beings from "the immediate form" of work, when dead labor valorizes living labor, then and seemingly only then are we on the brink of something new and possible (Merrifield 2013a, 23). 
The focus on immaterial and digital labour associated with a third phase of capitalismcognitive, cognitive-culture, informational, global-informational, informational-transnational, etc.-and its relationship and co-evolution with urbanization processes indicates that scholars must consider the geographies of digital labour and include analyses of urbanization in relation to capital accumulation and circulation.

We support Harvey's focus on urbanization as the physical and material excrescence of the circulation of capital, but suggest, in the vein of planetary urbanization, that this be expanded to include infrastructures vital to urbanization processes beyond the territory of the city as politically defined. Urbanization crosses political boundaries and regional identities, reaching globally, connecting people and industries separated by great distances. Following the infrastructures of digital ICTs can illustrate how urbanization, and its vital connection to the circulation of capital, reaches beyond the bounds of the city, aiding the increasingly immaterial forms of labour associated with planetary urbanization and cognitive-cultural production. As Marx and Engels explain in The German Ideology, "The greatest division of material and mental labor is the separation of town and country" (Marx and Engels 1978), but the materiality of "mental labour"-or cognitive and cultural labour-reaches beyond the city, invades the lifeworlds of a planet of urban residents, and excretes concrete, silicon, bits, servers, and energy waste producing an 'urban landscape' beyond the city.

\subsection{The City of CCC and Digital Labour: A Global Audience Commodity}

Scott's analysis of third-wave urbanization focuses on cities with a predominant cognitivecultural economy. Critics warn that such a focus might privilege theorization towards a smaller applicable population of urban inhabitants leading to a "telescopic view of the city" (Meagher 2013). However, Scott develops a framework for understanding contemporary, emergent patterns of urbanization that, as Wyly (2013) notes, can propel a radical political agenda that recognizes social knowledge as a direct force of production with socio-spatial impacts. We find Wyly's more critical analysis of $\mathrm{CCC}$, which takes planetary urbanization and technological change in a co-evolutionary perspective, to be a fitting extension of Scott's work with the Marxian political economic analyses of media and communication studies. The co-evolution of technological innovation and urbanization "is an essential feature of cognitivecultural capitalism" (Wyly 2013, 389). For Wyly, this co-evolution of technology and urbanization serves to increase the velocity of consumption. Wyly's formulation of the city of CCC critiques the "shitty positivism" of "the new social physics" emerging in the "neoliberal noosphere" where

[...] billions of smartphones, RFID (radio frequency identification) chips and QR (Quick Response) codes, and trillions of social-media data trails on preferences and purchases of physical commodities, services and media content. Data flood in, and the patternrecognition algorithms optimize and monetize attention, creativity and communication amidst the neoliberal wind that capitalizes, commodifies, classes, and marketizes everything. Social reality is ransacked, but not for theory: click-throughs, page views, eyeballs and ad revenue are what matter $(2013,392)$.

For Wyly, the attention spans of users are the raw materials for production of informational and advertising industries. Connecting Wyly's provocations with Smythe's "audience commodity" and broader discussions on digital labour, we suggest the urban becomes a central concern. The prosumer commodity, as in relation to Dallas Smythe's "audience commodity," elaborated by Fuchs (2012c) and others, refers to the exploitation of labor (surplus value creation) through processes of coercion, alienation, and appropriation enabled by digital technology and the harvesting of personal data. Fuchs discusses this process in terms of "Google Capitalism" (Fuchs 2012a), whereby surveillance is invested in the circuit of capital accumulation, and the Internet prosumer is both commodity and commodifier-as identity and consciousness are mined for data ("extracted knowledge") as a "natural" online digital resource in the formation of the advertisement commodity. As audiences produce data and consume ads specifically targeted to them, the urban is shaped to aid in this mode of production and in the circulation of capital. The global attention span, is an urban global audience 
commodity, packaged and sold as a prosumer commodity to the world's largest advertising companies, Google and Facebook. Third-wave urbanization under CCC transmits the digital labour of producers and prosumers into a planetary material force.

\section{Sites of Digital Labour and Value Production}

\subsection{Digital Labour "Beyond" the Screen}

In light of the growing scholarship on digital ICTs and digital labour (Hermann 2009; Arvidsson and Colleoni 2012; Andrejevic 2012; Fuchs and Sevignani 2013; Fuchs 2014; Mosco 2014; Qiu, Gregg, and Crawford 2014; Comor 2015; Rigi and Prey 2015), we point to the focus on immaterial and digital labour at the beginning of the production process and caution against a potentially telescopic view of labour. The growing forms of exploited and mechanized immaterial and digital labour in the full cycle of capital accumulation, particularly in capital circulation and urbanization, needs further explanation. In particular, theorizations about the connection between digital labour and cycles of capital accumulation have incited disagreement and confusion. In this on-going discussion scholars tend to focus on labour and production-generally the interaction between user or worker (of whatever type) and the digital device (its use or creation) - and fail to examine the larger process of surplus value creation, realization, and critically, circulation. This tendency renders digital labour as placeless and (in most cases) immaterial.

Research at the intersection of digital media and digital labour borrow the idea of immaterial labour from the tradition of autonomist Marxists. The immaterial form of labour is at the core of cognitive capitalism (Hardt and Negri 2004). Immaterial labour takes the form of services in mechanized manufacturing, cognitive "analytical and symbolic tasks", and the "production and manipulation of affect" (Hardt and Negri 2004, 293). While the main claim of theorists in this tradition is that a "new accumulation regime based on immaterial assets constitutes a new phase of capitalism" based on "intellectual, immaterial and digital" labour that are made possible from new technology, primarily digital communication technologies, that no longer depend on raw materials but on cognition, intellect and knowledge (Peters and Bulut 2011, xxxi).

Despite foundational work by Dallas Smythe calling to examine the materiality of communication technologies ${ }^{2}(1981)$, this contrast confuses the examination of the (socio-)material aspects of digital labour, digital ICT devices and digital ICT infrastructure. Research on digital media and technologies, and the internet more broadly, however, has recently taken a renewed interest in materiality and specifically Marx (Eagleton 2011; Fuchs 2012b). Fuchs and Sevignani (2013), Fuchs (2014), Fuchs and Sandoval (2014), and Qiu, Gregg and Crawford (2014) examined several cases of digital labour highlighting socio-material considerations mineral extraction under slave-like conditions in the Democratic Republic of Congo, manufacturing and assembly of digital technologies in China at Foxconn, software engineering in India and Silicon Valley, and prosumption by internet users. While these studies consider materiality by examining the various forms of digital labour, their discussion on the broader social, spatial and environmental impacts is limited.

The focus on "the screen"-a phone, tablet, or computer or other digital ICT device - has allowed scholars to link the interaction between users and the screen into their study of the relations of production of the digital ICT device with which the user interacts (Qiu, Gregg, and Crawford 2014; Fuchs and Sandoval 2014). This examination of the production of digital ICT devices opens up many sites involved in the "international division of digital labour" (Fuchs 2014) like the Foxconn plants in China where Apple iPhones are produced. In relation to the broader literature on materiality (outside of media and communication studies, in geography and UPE), scholarship on the political economy of media and communication contributes to an understanding of the social relations of digital labour at the site of production and consumption. However, it misses the socio-environmental impacts of

\footnotetext{
${ }^{2}$ Also noted by Fuchs (2012c, 694-695).
} 
the digital ICT device over its entire life-cycle-from production to disposal-and of the fixed capital infrastructure that enables the networked connectivity vital to user-screen interactions. The perception of "immaterial" labour as operating within the confines of a user-screen interaction obfuscates the larger physical infrastructures and spaces of digital ICTs that have coevolved with the cognitive-cultural economy and the contemporary networked city.

Referring to the specific case of the internet, Terranova explains that "[far] from being unreal, empty space, the internet is animated by cultural and technical labour through a continuous production of value that is completely immanent to the flows of the network society at large" (2000, 33-34). The digital economy, in this case, similar to Scott's cognitive-cultural economy, is a mixture of cultural economy and the information industry, and "an important area of [capitalist] experimentation with value and free cultural/affective labour" through "specific forms of production (web design, multimedia production, digital services, and so on), but it is also about forms of labour we do not immediately recognize as such: chat, real-life stories, mailing list, amateur newsletters, and so on" (2000, 38). Terranova's notion of free labour points the "immanent process of channelling collective labour (as cultural labour digital or immaterial) into monetary flows and its structuration within capitalist business practices" (39, emphasis added). Recent work by Cockayne shows how labour value, social values, and the affective attachments of digital media workers in San Francisco are structured, embedded, and transmitted through "hegemonic and seductive entrepreneurial working practices" (forthcoming); both shaping, and shaped by, San Francisco's urbanization, technical infrastructure, and their respective planetary reaches. In this paper, we argue that processes of channelling and structuration of labour is shaped, in part, by the socio-metabolic processes of capitalist urbanization coevolving with capitalist technological development. As such, the question of immaterial, digital, labour becomes not about the actions of users at their devices, but of the mode and social relations of production. Specifically, the moment of production of circulation that is facilitated by fixed capital infrastructures.

The type of immaterial labour discussed by Terranova (2000) and by Lazzarato (1996), for example, is seemingly in stark contrast to the formations of labour which rely on a direct interaction between man and "external" nature.

Labour is, first of all, a process between man and nature, a process by which man, through his own actions, mediates, regulates, and controls the metabolism between himself and nature. [...] Through this movement he acts upon external nature and changes it, and in this way he simultaneously changes his own nature [...] (Marx 1992, 283, 290).

Marx's oft cited formulation of labour is but one moment in the productive cycle. Labour represents the conversion of money to commodity, but there is still conversion of commodity back to money. Marx is, however, only giving one example of production here and in his own formulation of the circulation of capital, as discussed in Volume 2 of Capital, the metamorphoses of quantities of value, between $\mathrm{M}, \mathrm{C}$, and $\mathrm{M}$ ', play crucial parts.

This much has already been said that circulation itself is a moment of production, since only through circulation does capital become capital. [...] The more production comes to be based on exchange value, and thus on exchange, the more important for production do the physical conditions of exchange become-the means of communication and transport. [...] Circulation can create value only in so far as it requires additional employment-of alien labour-additional to that directly consumed in the production process (Marx 1993, 444-448,472 emphasis added).

From Marx, we see capitalism's evolution (towards a third-phase) that "the physical conditions of exchange"-or as in the predominately urban and urbanizing world, the urban - become ever more important for production. In CCC, then, the urban is vital socio-material space, an outcome of a more generalized urbanization process, for cognitive and cultural production. From Marx, we also see that circulation is part of the broader production process and surplus value can be added to the commodity if additional labour is applied for circulation. In this sense, we find immaterial labour to be caught in the realm of circulation and realization without connecting to the entire Marxian circuit of capital or to Harvey's circuits of cap- 
ital. Here it is worth noting that we do not wish to conflate conceptualizations of immaterial labour with digital labour. Instead we see digital labour as a subset of immaterial labour that is directly engaged with the use, production or prosumption of digital ICTs. However, we note that immaterial labour and the digital labour subset rely on a specific configuration of capitalism and capitalist circulation involving planetary urbanization, digital technologies, and fixed capital infrastructure.

\title{
3.2. Circulation as Production and Materiality of Immaterial Labour
}

As other theorists have noted, media, as a force on the relationship between time and space, is primarily concerned with circulation (Manzerolle and Kjøsen 2012). We suggest that because media and circulation are sensitive to time and space (communication and transport), media and circulation thrust planetary urbanization, circulation labour, and technological advancements centre stage in a competitive race to realize profit. This focus necessitates heeding Smythe's call to demystify the materiality of digital labour (Smythe 1981; Fuchs 2012c). We must examine beyond the production of a digital ICT device and beyond the labourer (user) interacting with the device. We examine the materiality of immaterial labour as human action that metabolizes nature through a socio-environmental relationship and shapes the consciousness of humans.

Similar clarifications have been made regarding materiality in seemingly immaterial sectors of industrial and economic development. Questioning the growing literature on the socalled "service" economy, Walker refuted the idea that the service labour of the "service" economy were in fact services. The rising temporal, spatial and technological complexity of industrial production meant that labour analysis was particularly difficult (1985). What we might call "service" labour - or even immaterial labour in media studies - is not a service at all. That is, "capitalist industrialism has not been transcended, but simply extended, deepened and perfected... the great majority of 'services' are the classic activities of a goods producing, industrial economy" (Walker 1985, 71-72). Walker's main argument is that the socalled service economy is comprised of what might be called immaterial activities.

\begin{abstract}
[The service economy] rests on the productive power of the industrial system. Consumption levels have risen and products proliferated. With the mass production and consumption of goods has come the mass of labor engaged in distribution centers, retail outlets, elaborate sales efforts, and transportation. The value produced along with the goods circulates through a massive financial structure, speeding exchanges, bridging time and space, leveraging capital accumulation. Specialized appendages have sprouted on this financial edifice, from leasing companies to secondary mortgage markets. Information about the economy swirls through communications channels created by that industry. Armies of managers rule over the system, paid out of the surplus of those they supervise; alongside them come the specialists in management inputs. In short, an enormous superstructure has been erected on the value and wealth generated by modern industry (Walker 1985, 72-73).
\end{abstract}

Merrifield, building on Lefebvre, conceptualizes the service economy as a "specialized appendage" of capitalism that includes financial structures and adds value through realization. This form of labour is the urban society and intricately linked to the urban (Merrifield 2013b, 23). Today, the temporal, spatial and technological complexity of industrial production has only increased and cities play a central role. Mass production and mass consumption have proliferated and developed, necessitating technologically advanced mass labour engaged in detailed production coordination, technologically advanced distribution centres, complex, targeted, and individualized sales and advertising, and advanced tracking and transportation. The financial structure has largely digitized, and new information about markets is leveraged in new financial instruments. Digital ICTs allow for the increased velocity of financial, communication and consumptive exchanges. New "armies of managers" are necessitated with the growth of these labour activities. Numerous forms of labour activities are involved in the production process by increasing the velocity of capital circulation so that the capitalist can realize profit sooner. Circulation, according to Marx, is itself a moment of production because 
it is only through circulation that capital becomes capital. In short, the enormous superstructure shaping, and shaped by, modern industry continues to become more complex.

In summary, a contemporary Marxian political economic analysis of digital technologies and digital labour requires the examination of the material infrastructure and flows that makes possible the addition of surplus value in circulation as a moment of production. In practice, this requires research on everything that happens "beyond the screen." Within digital media studies this may be focused on what happens both before and after a blog post is submitted, a post is liked, or a photo is uploaded. When a user accesses a Facebook image or post on a smartphone, the necessary Facebook content is retrieved and submitted through cell towers or an internet connection. Yet, media and communications scholars have not questioned where the material data is being stored and copied or how the data is being transmitted. Looking "beyond the screen" might involve research on the armies of labour activities and fixed capital infrastructure that make operation of digital ICT devices possible.

In the next section we will begin to examine the sites of, and actors involved with, data storage and transmission. Digital ICT devices are communication devices after all, and are materially connected to (digital) servers through (digital) infrastructure. It is through an examination of these sites of digital storage and communication that we gain a more comprehensive understanding of capital accumulation.

\section{Materializing Digital Labour}

We suggest that examining the geography of digital ICTs and digital labour under the planetary urban condition is a necessary step to analyse the materiality of digital labour. That is, the symbolic analysis and cognitive work of digital labourers is made possible only by their necessary connection to massive data storage and processing centres. This understanding raises several questions: What are the socio-spatial characteristics and impacts of these digital infrastructures? Where are data centres located and why in those specific locations? What are the socio-material impacts and benefits of data centres and how are they distributed? To answer these questions, an unearthing of the infrastructures of digital ICTs beyond the screen, both connections and nodes, becomes an essential task.

\subsection{Data Centres and Energy Use}

Data centres are far from cloud-like auras. Data centres are massive structures housing thousands of servers for storing data, advanced mechanical cooling and ventilation equipment, batteries and diesel generators for backup power and redundancy, and depending on the location and owner, a highly securitized shell of fencing and walls with limited access areas and surveillance systems. In a popular New York Times story in 2012, data centres were indicted for their energy intensive characteristics (Babcock 2012; Glanz 2012). The article pointed to Facebook's now seemingly "quaint" beginnings with only 10 million users, and how the company encountered data storage dilemmas of overheating, space limitations, and memory limitations at an early phase. Compared to today's scale, with the immensity of data produced by 1 billion users and stored on Facebook's data servers, their tiny rental space storing data used for the site in 2006 seems almost comically small.

By design, data centres are energy intensive. As the New York Times reported (these "cloud factories" use about 30 billion watts of electricity worldwide, roughly the same as 30 medium-sized nuclear or coal-fired power plants. Some data centres require "more power than a medium-size town" (Glanz 2012), and for this reason, "data centres are among [electric] utilities' most prized customers". The polluting impacts of the immense, steady demand on predominately coal-fired power facilities has exposed big data's 'dark side' (Oremus 2012), and even worse, the New York Times investigation showed that up to 90 percent of the energy consumed was wasted. In fact, data centres use $2 \%$ of all energy in the United States, which pales in comparison to 'dirty' industries like the paper industry (Oremus 2012).

The data centre industry responded first by addressing the errors in the New York Times analysis (Wilhelm 2012), and second, by improving energy efficiency and investing in renewable energy sources, effectively, or at least discursively, 'greening' their data centre opera- 
tions (cf Amazon.com 2014; Google 2015c). Facebook's Prineville, Oregon data centre is representative of the most efficient 'modern' data centres, which have much improved power usage effectiveness (PUE, or energy used overall divided by energy used for computing) from approximately 2.0 to near 1.07 (Babcock 2012). The technical characteristics of data centres, including their energy and land requirements, have shaped locational choices by data centre owners such as Facebook and Amazon: free air-cooling, low electricity rates, inexpensive land, and enterprise zones that limit taxation in places like Prineville, Oregon are key decision points. This poses further questions about the politics of development in places struggling to attract capital for economic development and jobs creation.

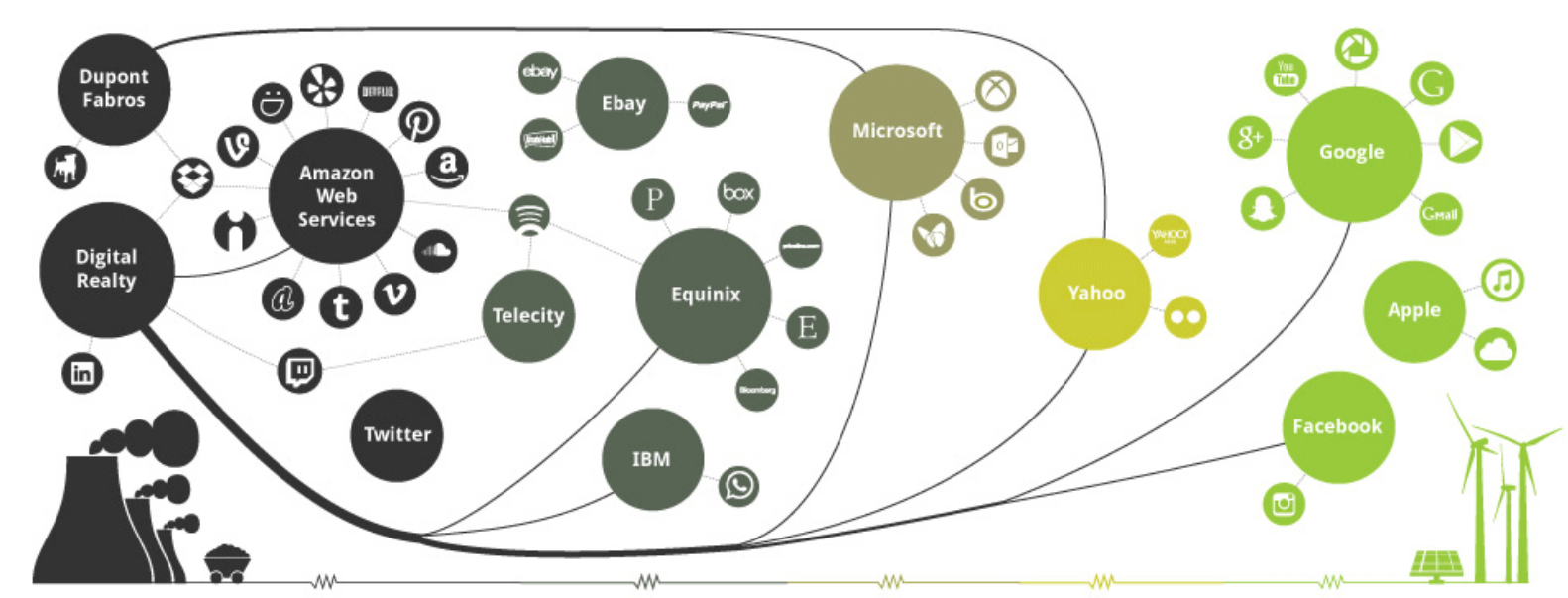

Figure 1: Greenpeace report on data centre sustainability (Cook and Van Horn 2011).

Non-governmental organizations have also stepped in to advocate for advancements in reducing polluting impacts and intensive energy consumption of data centres (McMillan 2014). Greenpeace, in particular, has focused on 'clicking clean' as an environmental strategy to influence companies like Amazon Web Services to use cleaner sources of energy. Despite attempts to increase the efficiency of data centres, the overall growth in data storage needs represents something of a Jevon's paradox that fuels more consumption and production of data and energy. In the era of "big data," where data is leveraged to solve all manner of social and environmental problems, expansive data centre growth is an established trend.

\subsection{The Geography of Data Centres}

In Table 1 we show the data centre locations of three large trans-national internet-based corporations: Facebook, Google and Amazon. The US state of Oregon has large data centres for all firms. Facebook has a large data centre in Prineville, Oregon. Apple, missing from the table, does not disclose all their locations, but also has a data centre next to the Facebook's Prineville, OR data centre. Google developed a data centre just east of Portland in The Dalles; it is one of only a handful of data centres whose value is over $\$ 1$ Billion USD (Miller 2013) and is featured regularly by the company because of its aesthetically pleasing internal design (Google 2015b). The data centre is located on the Columbia River dividing Oregon and Washington, adjacent to hydro-power facilities. 


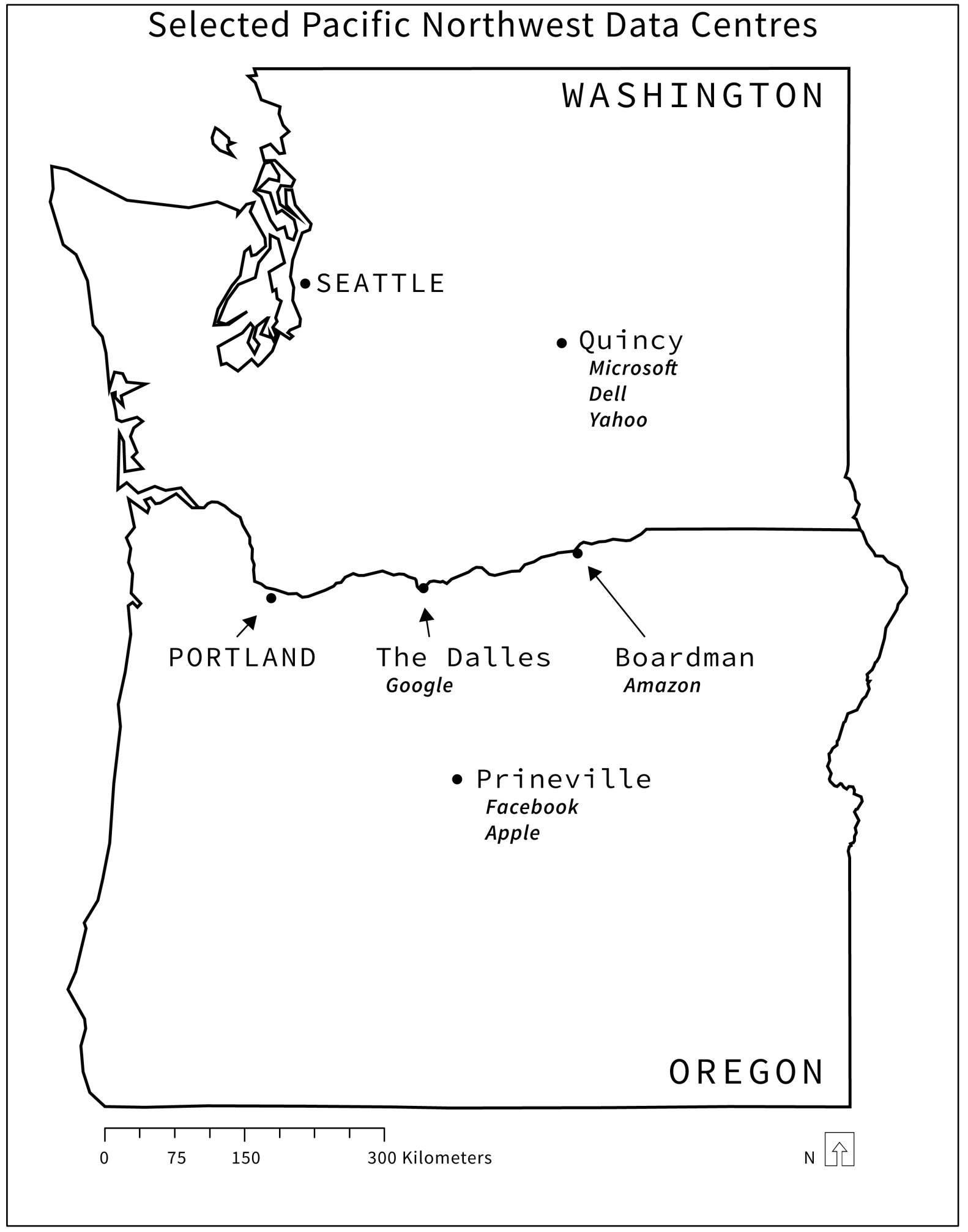

Figure 2: Selected Pacific Northwest Data Centres, see also Table 1

Amazon provides caching locations - small collections of servers that store data in locations more proximate to its users - outside major metropolitan areas throughout the western coast of the US. Amazon does not disclose specific locations of their data centres, however, at least one data centre exists in Boardman, Oregon (Rogoway 2011) and Amazon discloses that it has caching centres around large urban areas (Amazon.com 2015a). Amazon has planned expansion of data centres in rural Oregon pending Oregon's state legislature deci- 
sion regarding tax exemption for the facilities (Rogoway 2015a). Apple is also planning an expansion of the Prineville facility after both state tax changes and the expansion of the electricity capacity developed by the city of Prineville and Cook County. Quincy, Washington is home to one of the world's largest data centres owned by Microsoft and other large data centres from Dell and Yahoo.

These large firms do not have data centres in or around their Silicon Valley-based headquarters. Yet, firms locating their data centres in Oregon is no accident. Access to numerous intra- and international long-haul cable connect the region to other cable connections, providing high-bandwidth access across the globe. Inexpensive land, inexpensive hydro-power electricity, and high-bandwidth capacity make Oregon a prime location for data centres (Miller 2012a). Rising interest in building data centre's in Oregon led the Oregon government to reduce or remove property taxes on "intangible" and "hard to quantify" assets like company branding and computer equipment. During the state legislative hearings, Google and Amazon both testified that the original tax was preventing the companies from expanding their technical infrastructure. Google claimed that without the tax break, it could not develop its Google Fiber internet infrastructure in the city of Portland (Rogoway 2015c). The state elected to remove the tax hurdle, making exceptions for tech companies and their infrastructure. Shortly after the change in tax code, Amazon announced plans to build 11 more data centre's in the region (Rogoway 2015a). Similarly, Washington state, just north of Oregon on the other side of the Columbia River, passed a similar tax break targeted for data centres (Miller 2015b). In Oregon, the tax breaks made building data centres close to the city possible. Hillsboro, within the Portland metro region, is the future site of a reasonably sized 18,500 square meter data centre (Rogoway 2015b). Hillsboro is the terminus of three major longhaul cable submarine lines (Tyco Global Network Pacific, Southern Cross, and Trans-Pacific Express) connected to sites in Northern California, Japan and other places in Southeast Asia. Each cable line is over $20,000 \mathrm{~km}$ long (Submarine Cable Networks 2015). Within the Portland region, there are numerous land-based high-capacity long-haul cable connections to: Seattle and Tacoma in Washington; Boise, Idaho; Palo Alto, San Jose and Santa Clara in California; Cheyenne, Wyoming; and Kansas City, Missouri (TR 2014). A loop system that connects the Oregon coast and central Oregon's data centre's exist through a connection in Medford, Oregon (TR 2014).

Table 1 also shows the population of the nearest municipality for each data centre, the nearest large metropolitan area, and the nearest global city as defined by Beaverstock, Smith, and Taylor (2000) and Sassen (2009). These massive data centres do not merely serve the populations of the small municipalities where they are located, nor are the designed to serve the nearest large metropolitan area-which, for the Oregon data centres, is the Portland metropolitan region. This is not to diminish the growing agglomerations of software and technology companies in the Portland region, but simply acknowledging that the region is what Mayer (2012) calls a "second-tier" region known for its high-tech industries, but not of the scale of Silicon Valley or Los Angeles. Portland is known as the home of the annual Open Source Software Conference, home of the inventor of the wiki, home of the inventor of Linux, the location of Intel's largest manufacturing site and patents, and part of growing software and technology scene (Rogoway 2014). The two closest regions over 1 million in population have significant technology clusters. Seattle metro, the first region, is $280 \mathrm{~km}$ to the north and home to enterprise software firms Microsoft and Amazon (see also Figure 2). We refer to Amazon as a software firm because of its significant offerings for data storage, database management and its extensive network of servers which double to as digital infrastructure for its retail website. Silicon Valley, the second region $1,000 \mathrm{~km}$ to the south, is well known throughout the world and home to numerous technology companies, such as Facebook, Google and Apple (Silicon Valley includes the neighbouring metro regions of San Francisco and San Jose metro area). 


\begin{tabular}{|c|c|c|c|}
\hline Data Centre & Population & $\begin{array}{l}\text { Nearest metro } \\
\text { over } 1 \mathrm{mil} \text { in } \\
\text { population }\end{array}$ & $\begin{array}{l}\text { Nearest global } \\
\text { city** }\end{array}$ \\
\hline \multicolumn{4}{|l|}{ Facebook } \\
\hline Prineville, Oregon, USA & 9,000 & Portland, OR & Los Angeles, CA \\
\hline Forest City, North Carolina, USA & 7,000 & Charlotte, NC & Atlanta, GA \\
\hline Luleå, Sweden, USA & 46,000 & Stockholm & Copenhagen \\
\hline \multicolumn{4}{|l|}{ Google } \\
\hline $\begin{array}{r}\text { Unincorporated Berkeley County, South Caro- } \\
\text { lina, USA }\end{array}$ & 194,000 & Charlotte, NC & Atlanta, GA \\
\hline Council Bluffs, Iowa, USA & 62 & (Omaha, NE) & Chicago, IL \\
\hline Unincorporated Douglas County, Georgia, USA & 132,000 & Atlanta, GA & Atlanta, GA \\
\hline Quilicura, Chile & 200,000 & Santiago, Chile & Caracas, Venezuala \\
\hline $\begin{array}{r}\text { Unincorporated Mayes County, Oklahoma, } \\
\text { USA }\end{array}$ & 41,000 & $\begin{array}{l}\text { Oklahoma City, } \\
\text { OK }\end{array}$ & Chicago, IL \\
\hline Lenoir, North Carolina, USA & 18,000 & Charlotte, NC & Atlanta, GA \\
\hline The Dalles, Oregon, USA & 15,000 & Portland, OR & Los Angeles, CA \\
\hline Changhua County, Taiwan/China & $1,400,000$ & & \\
\hline Singapore & $5,500,000$ & (Singapore) & (Singapore) \\
\hline Hamina, Finland & 21,000 & & \\
\hline Saint-Ghislain, Belgium & 22,000 & & \\
\hline Dublin, Ireland & $1,100,000$ & (Dublin, Ireland) & London, UK \\
\hline Eemshaven port, Groningen, Netherlands & 580,000 & & \\
\hline \multicolumn{4}{|l|}{ Amazon US Data Centres } \\
\hline Boardman, Oregon, USA* & 3,000 & Portland, OR & Los Angeles, CA \\
\hline Unspecified, Northern California, USA* & NA & NA & Los Angeles, CA \\
\hline Unspecified, Northern Virginia, USA* & NA & NA & Washington, DC \\
\hline Unspecified, "GovCloud" USA* & NA & NA & NA \\
\hline
\end{tabular}

Table 2: Advertising and data revenue in millions (USD) for 2014

\begin{tabular}{|c|c|c|c|}
\hline Company & Total Revenue & Advertising Revenue & $\begin{array}{r}\text { Advertising Share of } \\
\text { Revenue }\end{array}$ \\
\hline Amazon & $\$ 88,988$ & $\$ 1,000^{*}$ & $1 \%$ \\
\hline Facebook & $\$ 12,466$ & $\$ 11,653^{*}$ & $93 \%$ \\
\hline Google & $\$ 66,001$ & $\$ 59,624$ & $90.3 \%$ \\
\hline Company & Total Revenue & $\begin{array}{r}\text { Data Service Reve- } \\
\text { nue }\end{array}$ & $\begin{array}{r}\text { Data Services Share } \\
\text { of Revenue }\end{array}$ \\
\hline Amazon & $\$ 88,988$ & $\$ 6,200^{*}$ & $7 \%$ \\
\hline
\end{tabular}

Amazon data from 2014 Annual Report (Amazon.com 2015b). Amazon advertising revenue estimated (Greene 2014). Amazon data services estimated (Babcock 2013). Facebook data from Facebook Investor Relations, advertising revenue estimated for Q4 2014 based on expectation (Facebook 2015). Google data from Google Financial Tables (Google 2015a).

Table 1: Data Centre Locations for Facebook, Google and Amazon

In this paper, we have highlighted Facebook, Google and Amazon as emblematic of the cognitive-cultural economy and representative of a cross-section of cognitive-cultural firms. These firms are undoubtedly trans-national digital technology and digital labour firms with a near universal presence within the United States. While not necessarily direct competitors, each firm has overlapping customer segments and all three rely on advertising as a source of revenue. Total revenue and advertising share of revenue is listed in Table 2. Facebook's social media platform is an advertising platform for its advertisers. Google, often thought of as a search-engine company, is primarily an advertising firm, which offers numerous other services like Gmail, mapping platforms, business platforms, Google Music streaming, Google Books, and support for its Android phone-based operating system. Amazon, often thought of 
as an online store, offers data storage, database management and caching services ("cloud computing") in addition to supporting its digital offerings for Amazon Books and Amazon Music. We do not discount Amazon's significant online retail store's 2014 revenue of nearly $\$ 70$ billion USD (Amazon.com 2015b), but also point to the shift of traditional retail competitors like Walmart and Target into the online space.

What becomes clear is the geography of production in cognitive-cultural capitalism. We show that a clustering of data centres in Oregon and the broader Pacific Northwest contrasted with a few data centres near the headquarters of trans-national internet-based and digital technology corporations Amazon, Facebook and Google. Portland, the nearest metro to many of the data centres, does not have the digital labour force or market to necessitate the capacity built in rural Oregon. Instead the regional digital labour and global reach of digital products produced by regional labour necessitate data centres near, but not at, the site of digital labourers. Urban high-tech and information technology firms and residents benefit from the use of data centres, utilizing technological networks and data centres located in the 'hinterland' with little or no benefit to rural municipalities (Glanz 2013). This geography complements the work by other scholars to understand the geography of domain name registrations during the dot-com era that demonstrated that registrations were not only dominated by Silicon Valley, but also concentrated in large urban areas (Zook 2000; Zook 2007).

Understanding the economic geography of labour and digital infrastructures, as shown in our analysis, helps to position the arguments about the uneven socio-environmental impacts of planetary urbanization under cognitive-cultural capitalism. Key to this understanding is how agglomerations of digital labourers - that is workers in high-tech and software industries which produce digital technologies that leverage digital ICTs - concentrate in urban areas. Amazon, Facebook and Google are, again, emblematic of cognitive-cultural capitalist production. Digital labourers performing symbolic and cognitive work in urban areas develop software and hardware for advertising to increase the velocity of consumption of existing material goods (Amazon does so directly). In other words, digital ICTs and digital labourers are employed to increase rate that capital is realized. We argue that the socio-environmental impacts are separated from the site of the symbolic and cognitive work of the digital labourer, producing uneven geographies of production, fixed capital infrastructure development, and socio-environmental impacts.

\subsection{The Urban Political Ecology of Data and Capital Circulation}

To analyse these socio-environmental impacts, we employ an urban political ecology (UPE) framework that builds on Lefebvre's notion of planetary urbanization. The UPE framework offers a more comprehensive understanding of digital labour and its explicit connection to places like rural Oregon and the broader Pacific Northwest. The globally connected data centres in Prineville, Boardman, and The Dalles, Oregon and Quincy, Washington power and enable the growth of technology agglomerations in urban areas on the west coast. When considering the socio-environmental impacts, the "clean" digital labour in urban areas is in stark contrast to the energy intensive digital machinery in rural areas. Expansions from Amazon, Google and Facebook in their Oregon data centres suggest that the relationship between these trans-national corporations and rural Oregon municipalities is favourable to both rural residents and the corporations. However, as we argue, the economic development benefits of data centres for rural Oregon are miniscule in comparison to the markets that they fuel. These data centres are backbones of the infrastructures that are used to increase the velocity of consumption of material goods through advertising and distribution. And, at the same time, the rural regions of Oregon are left with the negative socio-environmental outcomes associated with energy sourced from non-renewable sources.

In general, UPE explains how urban processes shape the way natural resources, or "natures," are manipulated and exploited while concurrently analyzing how urban metabolism and circulation-flows of resources into and out of the city - unfold in the context of uneven power relations, producing enabling and disabling social and environmental conditions (Heynen, Kaika, and Swyngedouw 2006). Early work in UPE focused on the intricate connec- 
tions between Lefebvrian notions of the urban and marxian views of metabolism to frame the human-environment relationship (Keil 2003; 2005). The focus of this research was on "the very networks of 'fetishized' urban infrastructures that urban political ecologists [...] described as the product of protracted struggles over the modernization of cities" (Keil 2005, 645). Networked infrastructures are "material mediators between nature and the city" (Kaika and Swyngedouw 2000, 120). And, despite new lenses on power relations and new objects of analysis (Lawhon, Ernstson, and Silver 2014), UPE retains a strong empirical focus on infrastructures and the materiality of cities in relation to environmental change (Monstadt 2009). Our discussion of digital ICT infrastructures (i.e. data centres) is supported by much of the scholarship on UPE which has traced how infrastructures can be unpacked to reveal the dynamics of spatio-historical capital accumulation processes, highlighting how capitalist power is enacted through urban materialities and class relations.

\begin{abstract}
Under capitalism, the commodity relation and the flow of money veils and hides the multiple socio-ecological processes of domination/subordination and exploitation/repression that feed the urbanization process and turn the city into a metabolic socio-environmental process that stretches from the immediate environment to the remotest corners of the globe [...] The environment of the city is deeply caught up in this dialectical process and environmental ideologies, practices and projects are part and parcel of this urbanization of nature process [...] In sum, the political-ecological examination of the urbanization process reveals the inherently contradictory nature of metabolic change and their technonatural 'metabolic vehicles' and teases out the inevitable conflicts (or the displacements there-of) that infuse socio-environmental change (Swyngedouw 2006, 106,115).
\end{abstract}

Following Swyngedouw, we assess the urban as a planetary "metabolic socio-environmental process" that at its very foundation is an outgrowth of capitalism. The transformation of nature and social relations inscribed within them are inextricably linked to urbanization (Smith 2008; Swyngedouw 2004; Swyngedouw 2006). If the urban is the "excrescence of the circulation of capital," then it takes on a socio-spatial form in relation to the mode of production. In cognitive-capitalism, this has meant a return to the urban centers, coupled with gentrification, and physical manifestations of the "new" division of labor in uneven geographical development that is global in scale. However, the focus on the city, with a token acknowledgement of those "low-value" spaces outside the city, has, at least in empirical research, left a gap in our understanding of the distant infrastructures that facilitate circulation and flows of "metabolized nature" in the form of capital, people, resources, and as we suggest for contemporary capitalism, data and information. In our empirical study above, we took account of the "remotest corners of the globe" that are no less involved in a digitally-facilitated urbanization process than the city itself.

\title{
5. Conclusion: Planetary Urbanization and Cognitive-Cultural Revolution
}

Wyly's (2013) extension and critique of Scott's work on cities of the third-wave provides us with a further consideration for interlinking the immaterial labour of CCC with Marx's own thinking on how "knowledge and human experience were becoming endogenized into the materiality of capitalist production" (390). Wyly quotes this epigraph from the Grundrisse to emphasize this point:

Nature builds no machines, no locomotives, railways, electric telegraphs, self-acting mules etc. These are products of human industry; natural material transformed into organs of the human will over nature, or of human participation in nature. They are organs of the human brain, created by the human hand; the power of knowledge, objectified. The development of fixed capital indicates to what degree general social knowledge has become a direct force of production, and to what degree, hence, the conditions of the process of social life itself have come under the control of the general intellect and been transformed in accordance with it. To what degree the powers of social production have been produced, not only in the form of knowledge, but as immediate organs of social practice, of the real life process (Marx 1857/58, 706, emphasis in original). 
The development of fixed capital, as we investigated in the infrastructures of digital ICTs, indicate the immense "degree general social knowledge has become a direct force of production." Certainly, this is inscribed in the process of planetary urbanization, which as Lefebvre noted, relied more and more on a process on "post-employment" or unwaged work (i.e. prosumption or audience labor). Together with Merrifield's suggestion that we are witnessing the urbanization of the general intellect, Lefebvre's thesis of complete urbanization should raise questions about the nature of labour in an urban society. As Merrifield (2013c) notes, "[the] degree to which human ingenuity, human imagination, scientific know-how and the vital powers of the human brain and hand have become objectified in fixed capital - capital that apparently rules over us - is the degree to which urban society defines our lives" (78).

We showed that digital ICTs are sophisticated manipulations of nature that require and illuminate new ways of thinking about digital labour, and more broadly, of immaterial labour. We suggest that the immaterial labour associated with digital ICTs is actually material labour involved in increasing the velocity of circulation as a moment of production, an appendage of the growing complexity of third-phase capitalist industry and urbanization. Unearthing the uneven geographies of digital ICT infrastructures, especially those beyond the screen, is an essential task for understanding the socio-environmental impacts of digital ICTs. Referring back to Marx and Engels, the cognitive, cultural, and symbolic work of digital labourers coincides with the argument that "the greatest division of material and mental labor is the separation of town and country" (Marx and Engels 1978). More importantly, the materiality of cognitive, cultural, and symbolic labour reaches beyond the city, invades the lifeworlds of a planet of urban residents, and produces uneven socio-environmental impacts producing beyond the city itself.

We demonstrated in this paper that the socio-environmental impacts of digital ICTs can fully be analyzed only if we consider the materiality of digital labour and digital ICT infrastructure. We illustrated this first by connecting analysis of digital ICTs to the co-evolution and geography of planetary urbanization and technological change, and second, relatedly, by connecting seemingly immaterial, digital, labour to the material industrial production system. Through an examination of data centres, we connect third-wave urbanization and its planetary reach into the pristine landscape of rural Oregon. Data centres in Oregon, and the broader Pacific Northwest, highlight the uneven geography of "clean" digital labour focused in large urban technopoles, the potentially harmful socio-environmental impacts of data centres in rural areas, and the necessary and dialectic relationship between the two for cognitivecultural capitalism. The massive material infrastructure "beyond the screen" makes digital labour possible, and at the same time, positions rural localities as the bearers of new energyintensive industries with little local socio-economic benefit. Together, digital ICTs and digital ICT infrastructure embody dialectic and material representation of both dead labour and the general intellect - shaping new, and uneven, socio-material natures and futures.

\section{References}

Amazon.com. 2014. AWS and Sustainable Energy. Amazon Web Services, Inc. http://aws.amazon.com/about-aws/sustainable-energy/.

Amazon.com. 2015a. Global Infrastructure. Amazon Web Services, Inc. http://aws.amazon.com/aboutaws/global-infrastructure/.

Amazon.com. 2015b. Amazon.com 2014 Annual Report. Amazon Web Services, Inc. April 24. http://phx.corporate-ir.net/phoenix.zhtml?c=97664\&p=irol-reportsAnnual.

Amin, Ash. 1994. Post-Fordism: Models, Fantasies and Phantoms of Transition. In Post-Fordism: A Reader, 1-39.

Amin, Ash, and Nigel Thrift. 2002. Cities: Reimagining the Urban. 1 edition. Cambridge: Polity.

Andrejevic, Mark. 2012. Exploitation in the Data Mine. In Internet and Surveillance: The Challenges of Web 2.0 and Social Media, edited by Christian Fuchs, Anders Albrechtslund, and Marisol Sandoval, 71-88. New York: Routledge.

Angelo, Hillary, and David Wachsmuth. 2014. Urbanizing Urban Political Ecology: A Critique of Methodological Cityism. International Journal of Urban and Regional Research 39 (1): 16-27. doi:10.1111/1468-2427.12105. 
Arvidsson, Adam, and Elanor Colleoni. 2012. Value in Informational Capitalism and on the Internet. The Information Society 28 (3): 135-50. doi:10.1080/01972243.2012.669449.

Babcock, Charles. 2012. N.Y. Times Data Center Indictment Misses Big Picture. InformationWeek. September 24.http://www.informationweek.com/cloud-computing/infrastructure/ny-times-datacenter-indictment-misses-b/240007880.

Babcock, Charles. 2013. Amazon's Cloud Revenues, Examined. InformationWeek. January 7. http://www.informationweek.com/cloud/infrastructure-as-a-service/amazons-cloud-revenuesexamined/d/d-id/1108058.

Beaverstock, Jonathan V., Richard G. Smith, and Peter J. Taylor. 2000. "World-City Network: A New Metageography?" Annals of the Association of American Geographers 90 (1): 123. doi:10.1111/0004-5608.00188.

Bluestone, Barry, and Bennett Harrison. 1982. The Deindustrialization of America: Plant Closings, Community Abandonment, and the Dismantling of Basic Industry. New York: Basic Books.

Brenner, Neil. 2013. Theses on Urbanization. Public Culture 25 (1 69): 85-114. doi:10.1215/08992363-1890477.

Brenner, Neil, and Christian Schmid. 2014. The 'Urban Age' in Question. International Journal of Urban and Regional Research 38 (3): 731-55. doi:10.1111/1468-2427.12115.

Brenner, Neil, and Christian Schmid. 2015. Combat, Caricature \& Critique in the Study of Planetary Urbanization: Reply to Critique by Richard Walker. Urban Theory Lab. http://www.urbantheorylab.net/publications/towards-a-new-epistemology-of-the-urban/.

Burdett, Richard, Teddy Cruz, and David Harvey. 2014. Uneven Growth: Tactical Urbanisms for Expanding Megacities. Edited by Pedro Gadanho. New York, NY: The Museum of Modern Art, New York.

Castells, Manuel. 1996. The Rise of the Network Society. Cambridge, MA: Blackwell.

Christophers, Brett. 2011. Revisiting the Urbanization of Capital. Annals of the Association of American Geographers 101 (6): 1347-64. doi:10.1080/00045608.2011.583569.

Cockayne, Daniel. forthcoming. Entrepreneurial Affect: Attachment to Work Practice in San Francisco's Digital Media Sector. Environment and Planning D: Society and Space

Comor, Edward. 2015. Revisiting Marx's Value Theory: A Critical Response to Analyses of Digital Prosumption. The Information Society 31 (1): 13-19. doi:10.1080/01972243.2015.977627.

Cook, Gary, and Jodie Van Horn. 2011. How Dirty Is Your Data? Amsterdam, The Netherlands: Greenpeace International. http://www.greenpeace.org/international/en/news/features/NewGreenpeace-report-digs-up-the-dirt-on-Internet-data-centres/.

Eagleton, Terry. 2011. Why Marx Was Right. Princeton, NJ: Yale University Press.

Facebook. 2015. Facebook Reports Fourth Quarter and Full Year 2014 Results. Feacebook. http://investor.fb.com/releasedetail.cfm?ReleaselD=893395.

Fuchs, Christian. 2012a. Google Capitalism. tripleC: Communication, Capitalism \& Critique. Open Access Journal for a Global Sustainable Information Society 10 (1): 42-48.

Fuchs, Christian. 2012b. Towards Marxian Internet Studies. tripleC: Communication, Capitalism \& Critique. Open Access Journal for a Global Sustainable Information Society 10 (2): 392-412.

Fuchs, Christian. 2012c. Dallas Smythe Today-The Audience Commodity, the Digital Labour Debate, Marxist Political Economy and Critical Theory. Prolegomena to a Digital Labour Theory of Value." tripleC: Communication, Capitalism \& Critique. Open Access Journal for a Global Sustainable Information Society 10 (2): 692-740.

Fuchs, Christian. 2014. Digital Labour and Karl Marx. 1 edition. Routledge.

Fuchs, Christian, and Marisol Sandoval. 2014. Digital Workers of the World Unite! A Framework for Critically Theorising and Analysing Digital Labour. tripleC: Communication, Capitalism \& Critique. Open Access Journal for a Global Sustainable Information Society 12 (2): 486-563.

Fuchs, Christian, and Sebastian Sevignani. 2013. "What Is Digital Labour? What Is Digital Work? What's Their Difference? And Why Do These Questions Matter for Understanding Social Media?" tripleC: Communication, Capitalism \& Critique. Open Access Journal for a Global Sustainable Information Society 11 (2): 237-93.

Glanz, James. 2012. Data Centers Waste Vast Amounts of Energy, Belying Industry Image. The New York Times, September 22. http://www.nytimes.com/2012/09/23/technology/data-centers-wastevast-amounts-of-energy-belying-industry-image.html.

Glanz, James. 2013. Is Big Data an Economic Big Dud? The New York Times, August 17, sec. Sunday Review. http://www.nytimes.com/2013/08/18/sunday-review/is-big-data-an-economic-bigdud.html. 
Google. 2015a. 2015 Financial Tables-Investor Relations-Google. Google Investor Relations. https://investor.google.com/financial/tables.html.

Google. 2015b. Data Centers. Google.com. http://www.google.com/about/datacenters/.

Google. 2015c. The Big Picture, Google Green. Google.com. http://www.google.com/green/bigpicture/.

Graham, Steve, and Simon Marvin. 2001. Splintering Urbanism: Networked Infrastructures, Technological Mobilities and the Urban Condition. Routledge.

Greene, Jay. 2014. "Amazon Easing into \$1B Sideline Business: Ad Sales." The Seattle Times, March 18. http://www.seattletimes.com/business/amazon-easing-into-1b-sideline-business-ad-sales/.

Hardt, Michael, and Antonio Negri. 2004. Multitude: War and Democracy in the Age of Empire. Reprint edition. New York, NY: Penguin Books.

Harrison, Bennett, and Barry Bluestone. 1985. The Great U-Turn: Corporate Restructuring and the Polarizing of America. New York: Basic Books.

Harvey, David. 1981. "The Spatial fix-Hegel, von Thunen, and Marx." Antipode 13 (3): 1-12.

Harvey, David. 1989. The Urban Experience. The Johns Hopkins University Press.

Harvey, David. 2014. "Video: The Crisis of Planetary Urbanization." presented at the The Political Economy Of Urbanization, Curitiba, Brazil, November 18. http://davidharvey.org/2015/04/video-thecrisis-of-planetary-urbanization/.

Hermann, Christoph. 2009. "Value and Knowledge: Insights from Marxist Value Theory for the Transformation of Work in the Digital Economy." Rethinking Marxism 21 (2): 275-89. doi:10.1080/08935690902743542.

Heynen, Nikolas C., Maria Kaika, and Erik Swyngedouw. 2006. In the Nature of Cities: Urban Political Ecology and the Politics of Urban Metabolism. Taylor \& Francis.

Heynen, Nikolas C., Harold A. Perkins, and Parama Roy. 2006. "The Political Ecology of Uneven Urban Green Space The Impact of Political Economy on Race and Ethnicity in Producing Environmental Inequality in Milwaukee." Urban Affairs Review 42 (1): 3-25. doi:10.1177/1078087406290729.

Kaika, Maria, and Erik Swyngedouw. 2000. "Fetishizing the Modern City: The Phantasmagoria of Urban Technological Networks." International Journal of Urban and Regional Research 24. http://kodu.ut.ee/ cect/teoreetilised\%20seminarid_2011/teoreetiline\%20seminar\%2014.09.2011/Ka ika_and_Swyngedouw.pdf.

Keil, Roger. 2003. "Urban Political Ecology." Urban Geography 24 (8): 723-38.

Keil, Roger. 2005. "Progress Report-urban Political Ecology." Urban Geography 26 (7): 640-51.

Lawhon, Mary, Henrik Ernstson, and Jonathan Silver. 2014. "Provincializing Urban Political Ecology: Towards a Situated UPE Through African Urbanism." Antipode 46 (2): 497-516. doi:10.1111/anti.12051.

Lazzarato, Maurizio. 1996. "Immaterial Labour." Radical Thought in Italy: A Potential Politics 1996: 133-47.

Lefebvre, Henri. 1992. The Production of Space. 1 edition. Malden, Mass.: Wiley-Blackwell.

Lefebvre, Henri.. 2003. The Urban Revolution. 1 edition. Minneapolis: Univ Of Minnesota Press.

Loftus, Alex. 2012. By Alex Loftus Everyday Environmentalism: Creating an Urban Political Ecology. Univ Of Minnesota Press.

Manzerolle, Vincent R., and Atle Mikkola Kjøsen. 2012. "The Communication of Capital: Digital Media and the Logic of Acceleration." tripleC: Communication, Capitalism \& Critique. Open Access Journal for a Global Sustainable Information Society 10 (2): 214-29.

Markusen, Ann, and Greg Schrock. 2006. "The Distinctive City: Divergent Patterns in Growth, Hierarchy and Specialisation." Urban Studies 43 (8): 1301-23.

Marx, Karl. 1993. Capital: Volume 2: A Critique of Political Economy. Translated by David Fernbach. Reprint edition. London: Penguin Classics.

Marx, Karl, and Friedrich Engels. 1978. The Marx-Engels Reader. Edited by Robert C. Tucker. 2nd Revised \& Enlarged. W. W. Norton \& Company.

Massey, Doreen B. 1995. Spatial Divisions of Labour: Social Structures and the Geography of Production. Basingstoke: Macmillan.

Matthew Zook. 2000. "The Web of Production: The Economic Geography of Commercial Internet Content Production in the United States." Environment and Planning A 32 (3): 411-26.

Matthew Zook. 2007. "The Geographies of the Internet." Annual Review of Information Science and Technology 40 (1): 53-78. doi:10.1002/aris.1440400109.

Mayer, Heike. 2012. Entrepreneurship and Innovation in Second Tier Regions. Edward Elgar Pub. 
McMillan, Robert. 2014. "Amazon and Twitter's Data Centers Flunk Greenpeace Report." WIRED. April 2. http://www.wired.com/2014/04/greenpeace/.

Meagher, Sharon M. 2013. "The Darker Underside of Scott's Third Wave." City 17 (3): 395-98. doi:10.1080/13604813.2013.807012.

Merrifield, Andy. 2012. "The Politics of the Encounter and the Urbanization of the World." City 16 (3): 269-83. doi:10.1080/13604813.2012.687869.

Merrifield, Andy. 2013a. "The Planetary Urbanization of Non-Work." City 17 (1): 20-36. doi:10.1080/13604813.2012.754176.

Merrifield, Andy. 2013b. "The Urban Question under Planetary Urbanization." International Journal of Urban and Regional Research 37 (3): 909-22.

Merrifield, Andy. 2013c. The Politics of the Encounter: Urban Theory and Protest Under Planetary Urbanization. University of Georgia Press.

Miller, Rich. 2008. "Where Amazon's Data Centers Are Located." Data Center Knowledge. November 18. http://www.datacenterknowledge.com/archives/2008/11/18/where-amazons-data-centers-arelocated/.

Miller, Rich. 2011. "A Look Inside Amazon's Data Centers." Data Center Knowledge. June 9. http://www.datacenterknowledge.com/archives/2011/06/09/a-look-inside-amazons-data-centers/.

Miller, Rich. 2013. "The Billion Dollar Data Centers.” Data Center Knowledge. April 29. http://www.datacenterknowledge.com/archives/2013/04/29/the-billion-dollar-data-centers/.

Miller, Rich. 2015. "Facebook DataCenter, Servers and Infrastructure FAQ." Data Center Knowledge. March. http://www.datacenterknowledge.com/the-facebook-data-center-faq/.

Miller, Rich. 2012a. "The New Data Center Geography." Data Center Knowledge. Accessed February 28. http://www.datacenterknowledge.com/archives/2012/02/28/the-new-data-center-geography/.

Miller, Rich. 2015b. "Washington State Passes Data Center Tax Breaks." Data Center Knowledge. Accessed June 22. http://www.datacenterknowledge.com/archives/2012/04/16/washington-staterestores-data-center-tax-breaks/.

Monstadt, Jochen. 2009. Conceptualizing the Political Ecology of Urban Infrastructures: Insights from Technology and Urban Studies. Environment and Planning. A 41 (8): 1924.

Mosco, Vincent. 2014. To the Cloud: Big Data in a Turbulent World. Boulder: Paradigm Publishers.

Moulier-Boutang, Yann. 2012. Cognitive Capitalism. 1 edition. Cambridge, UK; Malden, MA: Polity.

Oremus, Will. 2012. "Big Data's Dark Side: A Massive, Polluting Drain on the Nation's Power Supply." Slate, September 24.

http://www.slate.com/blogs/future_tense/2012/09/24/big_data_pollution_cloud_servers_waste_elec tricity on massive scale new york times finds_html.

Peters, Michael A., and Ergin Bulut, eds. 2011. Cognitive Capitalism, Education and Digital Labor. 1 edition. New York: Peter Lang Publishing Inc.

Piore, Michael, and Charles Sabel. 1986. The Second Industrial Divide: Possibilities For Prosperity. Basic Books.

Qiu, Jack Linchuan, Melissa Gregg, and Kate Crawford. 2014. Circuits of Labour: A Labour Theory of the iPhone Era. tripleC: Communication, Capitalism \& Critique. Open Access Journal for a Global Sustainable Information Society 12 (2): 564-81.

Rigi, Jakob, and Robert Prey. 2015. Value, Rent, and the Political Economy of Social Media. The Information Society 31 (5): 392-406. doi:10.1080/01972243.2015.1069769.

Rogoway, Mike. 2011. Amazon Confirms Its Data Center near Boardman Has Begun Operating." OregonLive.com, September 9. http://www.oregonlive.com/siliconforest/index.ssf/2011/11/amazon confirms its data cente.html.

Rogoway, Mike. 2014. Oregon Tech Employment Hits 12-Year High as Software Plays a Growing Role. Oregon Live, September 16. http://www.oregonlive.com/siliconforest/index.ssf/2014/09/oregon tech_employment hits_12.html.

Rogoway, Mike. 2015a. "Amazon Plans up to 11 More Oregon Data Centers If Tax Situation Addressed." OregonLive.com, February 8. http://www.oregonlive.com/siliconforest/index.ssf/2015/02/amazon_plans up to 11 more_ore.html.

Rogoway, Mike. 2015b. "ViaWest Building New, 200,000-Square-Foot Data Center in Hillsboro." OregonLive.com, February 9. http://www.oregonlive.com/siliconforest/index.ssf/2015/02/viawest building new 200000-sq.html.

Rogoway, Mike. 2015c. "Tax Cuts for Google Fiber, Comcast and Data Centers Move Forward in Oregon Senate, but Cities Object." OregonLive.com, February 27. http://www.oregonlive.com/siliconforest/index.ssf/2015/02/tax changes for google fiber_c.html. 
Sassen, Saskia. 2009. Cities in Today's Global Age. SAIS Review 29 (1): 3-34.

Scholz, Trebor, ed. 2012. Digital Labor: The Internet as Playground and Factory. Routledge.

Scott, Allen J. 1986. Industrial Organization and Location: Division of Labor, the Firm, and Spatial Process. Economic Geography, 215-31.

Scott, Allen J. 2009. Social Economy of the Metropolis: Cognitive-Cultural Capitalism and the Global Resurgence of Cities. Oxford ; New York: Oxford University Press.

Scott, Allen J. 2011a. Emerging Cities of the Third Wave. City 15 (3-4): 289-321. doi:10.1080/13604813.2011.595569.

Scott, Allen J. 2011b. A World in Emergence: Notes Toward a Resynthesis of Urban-Economic Geography for the 21st Century. Urban Geography 32 (6): 845-70. doi:10.2747/0272-3638.32.6.845.

Scott, Allen J. 2014. Beyond the Creative City: Cognitive-Cultural Capitalism and the New Urbanism. Regional Studies 48 (4): 565-78. doi:10.1080/00343404.2014.891010.

Smith, Neil. 2005. The New Urban Frontier: Gentrification and the Revanchist City. Hoboken: Taylor and Francis.

Smith, Neil. 2008. Uneven Development: Nature, Capital, and the Production of Space. 3rd ed. University of Georgia Press.

Smythe, Dallas W. 1981. Dependency Road: Communications, Capitalism, Consciousness, and Canada. Norwood, N.J: Praeger.

Storper, Michael, and Richard Walker. 1989. The Capitalist Imperative: Territory, Technology, and Industrial Growth. Oxford, UK; New York, NY, USA: B. Blackwell.

Submarine Cable Networks. 2015. "TPE Hillsboro Cable Landing State." Submarine Cable Networks | The World of Submarine Cable Systems and Networks. http://www.submarinenetworks.com/stations/north-america/usa-west/hillsboro-tpe.

Sussman, Gerald. 1999. Urban Congregations of Capital and Communications: Redesigning Social and Spatial Boundaries. Social Text, no. 60 (October): 35-51.

Swyngedouw, Erik. 2004. Globalisation or 'Glocalisation'? Networks, Territories and Rescaling. Cambridge Review of International Affairs 17 (1). http://web.iaincirebon.ac.id/ebook/moon/BureaucracyGovernance/cria.pdf.

Swyngedouw, Erik. 2006. "Circulations and Metabolisms: (Hybrid) Natures and (Cyborg) Cities." Science as Culture 15 (2): 105-21. doi:10.1080/09505430600707970.

Swyngedouw, Erik. 2009. "The Political Economy and Political Ecology of the Hydro-Social Cycle." Journal of Contemporary Water Research \& Education 142 (1): 56-60. doi:10.1111/j.1936704X.2009.00054.x.

Swyngedouw, Erik, Maria Kaika, and Esteban Castro. 2002. "Urban Water: A Political-Ecology Perspective." Built Environment (1978-) 28 (2): 124-37.

Terranova, Tiziana. 2000. Free Labor: Producing Culture for the Digital Economy. Social Text, no. 63: 33.

TR. 2014. Network Maps: USA Longhaul. Telecom Ramblings. http://www.telecomramblings.com/network-maps/usa-fiber-backbone-map-resources/.

Vercellone, Carlo. 2007. From Formal Subsumption to General Intellect: Elements for a Marxist Reading of the Thesis of Cognitive Capitalism. Historical Materialism 15 (1): 13-36.

Walker, Richard A. 1978. Two Sources of Uneven Development Under Advanced Capitalism: Spatial Differentiation and Capital Mobility. Review of Radical Political Economics 10 (3): 28-38. doi:10.1177/048661347801000304.

Walker, Richard A. 1985. Is There a Service Economy? The Changing Capitalist Division of Labor. Science \& Society 49 (1): 42-83.

Wilhelm, Alex. 2012. Microsoft Responds to the NYTimes. The Next Web. September 25. http://thenextweb.com/microsoft/2012/09/25/microsoft-responds-nytimes-data-center-article-gentlypointing-its-bunk/.

Wyly, Elvin. 2013. The City of Cognitive-cultural Capitalism. City 17 (3): 387-94. doi:10.1080/13604813.2013.807014.

Zip, Larissa, Rebekah Parker, and Elvin Wyly. 2013. "Facebook as a Way of Life: Louis Wirth in the Social Network." Geographical Bulletin 54 (2): 77-98. 


\section{About the Authors}

Dillon Mahmoudi

Dillon Mahmoudi is a PhD Candidate in the Toulan School of Urban Studies and Planning at Portland State University. His research and publications lie at the intersection of economic geography, labour, and digital technology. In his dissertation, he examines the economic geography of firm and labour practices in software firms through a relational case study of three US cities.

\section{Anthony Levenda}

Anthony Levenda is a PhD Candidate in the Toulan School of Urban Studies and Planning at Portland State University. His research and publications lie at the intersection of urban geography, political economy, and sociology of technology. His dissertation project examines the political economy and ecology of networked urban infrastructures by focusing on smart grid and smart city technologies and related markets. 